University of Nebraska - Lincoln

DigitalCommons@University of Nebraska - Lincoln

Faculty Papers and Publications in Animal

Science

Animal Science Department

2000

\title{
Evaluation of Feather Meal as a Source of Sulfur Amino Acids for Growing Steers
}

\author{
M. J. Klemesurd \\ University of Nebraska-Lincoln \\ Terry Klopfenstein \\ University of Nebraska-Lincoln, tklopfenstein1@unl.edu \\ Austin Lewis \\ University of Nebraska-Lincoln, alewis2@unl.edu
}

Follow this and additional works at: https://digitalcommons.unl.edu/animalscifacpub

Part of the Animal Sciences Commons

Klemesurd, M. J.; Klopfenstein, Terry; and Lewis, Austin, "Evaluation of Feather Meal as a Source of Sulfur Amino Acids for Growing Steers" (2000). Faculty Papers and Publications in Animal Science. 528.

https://digitalcommons.unl.edu/animalscifacpub/528

This Article is brought to you for free and open access by the Animal Science Department at DigitalCommons@University of Nebraska - Lincoln. It has been accepted for inclusion in Faculty Papers and Publications in Animal Science by an authorized administrator of DigitalCommons@University of Nebraska - Lincoln. 


\title{
Evaluation of feather meal as a source of sulfur amino acids for growing steers ${ }^{1}$
}

\author{
M. J. Klemesrud, T. J. Klopfenstein ${ }^{2}$, and A. J. Lewis
}

Department of Animal Science, University of Nebraska, Lincoln 68583-0908

\begin{abstract}
In situ and digestion studies were conducted to evaluate feather meal (FTH), blood meal (BM), and meat and bone meal (MBM) for escape protein content, amino acid composition of the escape protein, true protein digestibility, and digestibility of the individual amino acids. Following $12 \mathrm{~h}$ of ruminal incubation, escape protein values were $73.5,92.4$, and $60.8 \%$ of CP for FTH, BM, and MBM, respectively. Blood meal and MBM were poor sources of sulfur amino acids (SAA), whereas FTH was a good source. Most of the SAA of FTH, however, was Cys, with very little Met. True protein digestibilities were not different for the protein sources $(P>.15)$, ranging from 86.7 to $94.0 \%$ of the CP. However, digestibilities of the individual amino acids were quite different. Two growth studies were conducted to evaluate FTH as a source of SAA for growing cattle. The first study used 120 steers $(228 \pm 15 \mathrm{~kg})$ supplemented with urea, MBM, MBM plus $1 \% \mathrm{FTH}$, or MBM plus 2\% FTH. Additionally, incremental amounts of rumen-protected Met were added to treat-
\end{abstract}

ments containing MBM. Supplementation of MBM increased $(P<.05)$ ADG compared with the urea control. Addition of FTH to MBM resulted in a linear $(P<.01)$ increase in ADG. However, addition of rumen-protected Met to MBM plus FTH treatments further improved gains. Although FTH is an effective source of SAA, Met probably was first-limiting. The second study used 90 steers $(243 \pm 18 \mathrm{~kg})$ supplemented with BM plus incremental amounts of SAA from either FTH or rumenprotected Met. Addition of SAA improved ADG compared with BM alone $(P<.05)$. Rumen-protected Met as a source of SAA improved ADG compared with FTH $(P<.05)$. The SAA from FTH promoted a gain response equal to $50 \%$ of the response obtained with rumenprotected Met. Formulation of ruminant diets for metabolizable amino acids must account for escape value and digestibility of each individual amino acid. Feather meal is an effective source of SAA; however, Cys supplies over five times the amount supplied by Met.

Key Words: Beef Cattle, Feather Meal, Methionine, Cystine

(2000 American Society of Animal Science. All rights reserved.

J. Anim. Sci. 2000. 78:207-215

\section{Introduction}

Growing calves consuming forage diets often are deficient in metabolizable protein MP; Wilkerson et al., 1993). To meet the MP requirement of the animal and increase $\mathrm{ADG}$, escape protein sources generally are supplemented (Goedeken et al., 1990a; Gibb et al., 1992b; Klemesrud et al., 1997b). However, sources of escape protein vary markedly in amino acid content, influencing the supply of metabolizable amino acids available for the animal (Merchen and Titgemeyer, 1992).

Meat and bone meal (MBM) is a good source of escape protein, but it is deficient in Met (Klemesrud et al., 1997b). Supplementation of rumen-protected Met in-

\footnotetext{
${ }^{1}$ Published with the approval of the director as paper no. 12474 , journal ser., Nebraska Agric. Res. Div.

${ }^{2}$ To whom correspondence should be addressed.

Received January 28, 1999.

Accepted July 15, 1999.
}

creased ADG and protein efficiency in steers fed MBM (Klemesrud et al., 1997a). Blood meal (BM), also an excellent source of escape protein, may be deficient in sulfur amino acids (SAA). Addition of feather meal (FTH) to BM has resulted in improved daily gain and protein efficiency in growing steers, compared with either meal fed alone (Goedeken et al., 1990b). Feather meal is also an excellent source of escape protein and SAA. However, FTH contributes primarily Cys rather than Met (Goedeken et al., 1990a,b).

A physiological requirement exists for both Met and Cys. A dietary requirement, however, exists only for Met (Reis et al., 1973), because Cys can be synthesized from Met. The reverse reaction does not occur. This does not mean that dietary sources of Cys cannot be utilized. On the contrary, dietary Cys can supply part of the need for total SAA (Ahmed and Bergen, 1983).

This research was conducted to evaluate FTH as a source of SAA in growing calves and to determine the extent to which cystine can contribute to the SAA requirement of the animal. 


\section{Materials and Methods}

In Situ Study. Samples of MBM, BM, and FTH were incubated in situ according to the procedures of Wilkerson et al. (1995) to estimate escape protein and escape amino acid content. Approximately $4 \mathrm{~g}$ of each protein source was placed in each of four Dacron bags $(10 \times 20$ cm; $50 \mu \mathrm{m}$ pore size; du Pont, Wilmington, DE). Each bag was sealed by wrapping the top around a \#8 rubber stopper and securing it with a \#18 rubber band. The bag was then folded over the rubber band, and a second rubber band was added. Sample bags were placed in a $36-\times 42-\mathrm{cm}$ polyester bag made of mesh material and closed with a nylon zipper. To facilitate hydration, the bag was soaked in $39^{\circ} \mathrm{C}$ water for 20 min before ruminal incubation. The bag was placed in the liquid phase of the ruminal ventral sac of a mature, ruminally cannulated crossbred steer fed at maintenance on a grass hay diet.

Following $12 \mathrm{~h}$ of ruminal incubation (Wilkerson et al., 1993), the bag was removed from the rumen and washed by hand until the rinse water was clear. Sample bags were then dried in a $60^{\circ} \mathrm{C}$ forced-air oven for 24 h. Total N (AOAC, 1984) was determined before and after ruminal incubation to estimate the amount of ruminal escape protein for each source.

Residue remaining after incubation was composited by protein source and analyzed for amino acid content (Klemesrud et al., 1997b). Samples were hydrolyzed in $6 \mathrm{~N} \mathrm{HCl}$, and amino acid content of hydrolyzates was determined with ion-exchange chromatography (AOAC, 1984). Separate samples were oxidized with performic acid for analysis of Cys and Met (AOAC, 1984). All analyses were conducted in duplicate.

The GLM procedures of SAS (1985) were used to analyze the protein degradation data. The experiment was of a completely randomized design, and the statistical model included protein source and error. Least significant differences (F-protected; SAS, 1985) were used to separate treatment means.

Digestion Study. Crossbred wether lambs $(\mathrm{n}=32$; $54.8 \pm 3.3 \mathrm{~kg}$ ) housed in individual metabolism crates were fed a basal diet (Table 1) containing ensiled corn cobs and alfalfa pellets. Management of animals was approved by the institutional animal care committee. The basal diet was fed to all lambs at $1.6 \%$ of BW (DM basis) throughout the trial. This maintenance diet was formulated to provide a minimum of $10 \% \mathrm{CP}, 52 \% \mathrm{TDN}$, $.42 \% \mathrm{Ca}$, and $.18 \% \mathrm{P}$. Urea was included in the basal diet to ensure that rumen $\mathrm{NH}_{3}$ was not limiting digestion and provided $44 \%$ of the basal dietary CP.

This study consisted of a 14-d adaptation period and a 7-d fecal collection period. Lambs were assigned randomly to treatment protein source; eight lambs were assigned to each of the three protein sources or an unsupplemented control. Supplemental protein sources were fed at $3.75 \%$ of the basal diet DMI as units of additional CP. Therefore, the supplemental DMI in addition to the basal diet was dependent on the $\mathrm{CP}$ content
Table 1. Composition of basal diet fed in lamb digestion trial

\begin{tabular}{lc}
\hline \hline Ingredient & $\%, \mathrm{DM}$ \\
\hline Ensiled corn cobs & 72.70 \\
Alfalfa pellets & 15.00 \\
Ground corn & 10.00 \\
Urea & 1.48 \\
Dicalcium phosphate & .26 \\
Salt & .30 \\
Ammonium sulfate & .17 \\
Trace minerals $^{\mathrm{a}}$ & .04 \\
Vitamins $^{\mathrm{b}}$ & .03 \\
Selenium $^{\mathrm{c}}$ & .02 \\
\hline
\end{tabular}

${ }^{\mathrm{a} C o n t a i n s ~} 10 \% \mathrm{Mg}, 6 \% \mathrm{Zn}, 4.5 \% \mathrm{Fe}, 2 \% \mathrm{Mn}, .5 \% \mathrm{Cu}$, and $.3 \% \mathrm{I}$.

${ }^{\mathrm{b}} 15,000 \mathrm{IU}$ vitamin $\mathrm{A}, 3,000 \mathrm{IU}$ vitamin $\mathrm{D}$, and $3.75 \mathrm{IU}$ vitamin $\mathrm{E}$ per gram of premix.

'Premix contains $.06 \%$ Se.

of the treatment protein source. All diets containing treatment proteins were isonitrogenous and contained $13.75 \% \mathrm{CP}$, and the unsupplemented control diet contained $10 \% \mathrm{CP}$. Treatment protein sources were individually weighed and hand-mixed into the basal diet at the time of feeding.

Lambs were weighed before the trial to enable feeding of diets on an equal percentage of BW. Lambs were fitted with fecal collection bags to allow for total fecal collection. Feces were collected daily and weighed, and a $10 \%$ subsample was taken. Subsamples were composited by lamb for the 7-d collection period. Feed, feces, and orts were oven-dried $\left(60^{\circ} \mathrm{C}\right)$, ground through a 1$\mathrm{mm}$ screen, and analyzed for DM and CP content (AOAC, 1984). Fecal samples were composited by treatment protein source and analyzed for amino acid content using the procedures previously described.

True protein digestibility and true digestibility for the individual amino acids that escaped ruminal degradation were calculated by difference from the unsupplemented-control sheep as outlined by Blasi et al. (1991). Results were analyzed as a completely randomized design using the GLM procedures of SAS (1985) with the model containing protein source. Least significant differences (F-protected; SAS, 1985) were used to separate treatment means.

Growth Trials. Two calf growth trials were conducted to evaluate FTH as a source of SAA for growing cattle based on ADG response. Trial 1 used medium-framed crossbred beef steers ( $\mathrm{n}=120 ; 228 \pm 15 \mathrm{~kg}$ initial BW) assigned randomly to one of four dietary treatments. Treatments consisted of either a urea supplement, MBM supplement, MBM supplement plus $1 \% \mathrm{FTH}$, or MBM plus 2\% FTH (Table 2). The inclusion of MBM (6.4\%) was equal among the three supplements and formulated to supply $70 \mathrm{~g} / \mathrm{d}$ of metabolizable protein. This assumes diet consumption at $2 \% \mathrm{BW}$ based on previous research. The low inclusion of FTH (1\%) was formulated to provide $30 \mathrm{~g} / \mathrm{d}$ of metabolizable protein or $1.5 \mathrm{~g} / \mathrm{d}$ of metabolizable SAA. The high inclusion of 
Table 2. Composition of diets (\%, DM basis) fed to growing steers in Trial $1^{\text {a }}$

\begin{tabular}{|c|c|c|c|c|}
\hline \multirow[b]{2}{*}{ Ingredient } & \multicolumn{4}{|c|}{ Treatment } \\
\hline & Urea & $\mathrm{MBM}^{\mathrm{bc}}$ & $\begin{array}{c}\text { MBM+ } \\
1 \% \mathrm{FTH}^{\mathrm{cd}}\end{array}$ & $\begin{array}{c}\text { MBM+ } \\
2 \% \mathrm{FTH}^{\mathrm{cd}}\end{array}$ \\
\hline Sorghum silage & 44 & 44 & 44 & 44 \\
\hline Ground corncobs & 44 & 44 & 44 & 44 \\
\hline Dry supplement & 12 & 12 & 12 & 12 \\
\hline Corncobs & 4.80 & 1.20 & .65 & .10 \\
\hline Inert fat ${ }^{\mathrm{e}}$ & 1.20 & .30 & .16 & .02 \\
\hline Urea & 2.16 & 1.22 & .89 & .57 \\
\hline Dicalcium phosphate & .99 & - & - & - \\
\hline Meat and bone meal & - & 6.43 & 6.43 & 6.43 \\
\hline Feather meal & - & - & 1.02 & 2.03 \\
\hline Soybean hulls & 2.06 & 2.06 & 2.06 & 2.06 \\
\hline Salt & .30 & .30 & .30 & .30 \\
\hline Tallow & .20 & .20 & .20 & .20 \\
\hline Ammonium sulfate & .20 & .20 & .20 & .20 \\
\hline Trace mineral premix ${ }^{f}$ & .05 & .05 & .05 & .05 \\
\hline Vitamin premix ${ }^{g}$ & .03 & .03 & .03 & .03 \\
\hline Selenium premix ${ }^{\mathrm{h}}$ & .01 & .01 & .01 & .01 \\
\hline
\end{tabular}

a Diets were $60 \%$ TDN, $11.1 \% \mathrm{CP}$, and $69 \% \mathrm{NDF}$.

${ }^{\mathrm{b}} \mathrm{MBM}=$ Meat and bone meal produced from high ash (bone) offal from cattle slaughter.

${ }^{\mathrm{c}}$ Rumen-protected Met added to provide incremental amounts of additional metabolizable Met $(0,1,2,3$, 4 , or $6 \mathrm{~g} / \mathrm{d}$ ).

${ }^{\mathrm{d}} \mathrm{FTH}=$ Feather meal hydrolyzed at $145^{\circ} \mathrm{C}$ for $15 \mathrm{~min}$.

${ }^{\text {e} A l i f e t}$ (Alifet USA, Cincinnati, OH).

${ }^{\mathrm{f} C o n t a i n s ~} 10 \% \mathrm{Mg}, 6 \% \mathrm{Zn}, 2 \% \mathrm{Mn}, 4 \% \mathrm{Fe}, .5 \% \mathrm{Cu}, .3 \% \mathrm{I}$, and $.05 \% \mathrm{Co}$.

${ }^{g} 15,000 \mathrm{IU}$ of vitamin A, 3,000 IU of vitamin D, and $3.75 \mathrm{IU}$ vitamin E per gram of premix.

${ }^{\text {h}}$ Premix contained $.06 \%$ Se.

FTH (2\%) was formulated to provide $60 \mathrm{~g} / \mathrm{d}$ of metabolizable protein or $3 \mathrm{~g} / \mathrm{d}$ of metabolizable SAA.

Additionally, in each of the three MBM treatments, steers were assigned randomly to one of six incremental amounts of rumen-protected Met supplementation (Smartamine M; Rhône-Poulenc Animal Nutrition, Atlanta, GA). These amounts of actual metabolizable Met were $0,1,2,3,4$, or $6 \mathrm{~g} / \mathrm{d}$. Smartamine $M$ contains Met (63\% metabolizable Met) encapsulated in a $\mathrm{pH}-$ sensitive coating (poly-2-vinyl-pyridine-co-styrene) that is stable at a ruminal $\mathrm{pH}$ of 5.4 yet loses its integrity when it enters the abomasum (Polan et al., 1991). Six calves were randomly assigned to the urea control and eight calves each to MBM, MBM plus $1 \% \mathrm{FTH}$, and MBM plus 2\% FTH. Six calves were assigned to each level of Met.

Trial 2 used medium-framed crossbred beef steers ( $\mathrm{n}$ $=90 ; 243 \pm 18 \mathrm{~kg}$ ) assigned randomly to one of two treatments, which consisted of either a BM supplement plus incremental amounts of FTH or a BM supplement plus incremental amounts of rumen-protected Met (Smartamine M; Table 3). The inclusion of BM (2.6\%) was equal between supplements and formulated to supply $106 \mathrm{~g} / \mathrm{d}$ of metabolizable protein. The NRC (1996) equations predicted that this amount of BM would provide adequate amounts of all essential amino acids with the exception of Met and SAA. Level 1 (NRC, 1996) was used to predict metabolizable protein flow and requirements. Amino acid composition of metabolizable protein supply was from Klemesrud et al. (2000) and requirement from NRC (1996). Total sulfur amino acid require- ments were further estimated from Wilkerson et al. (1993). Feather meal or rumen-protected Met were added at incremental amounts to provide $0, .25, .5,1$, $1.5,2,4$, or $6 \mathrm{~g} / \mathrm{d}$ (.25 g/d level of FTH not included) of metabolizable SAA. Eighteen calves were randomly assigned to the BM control. Seven calves were assigned to each total SSA level of .25 to $1.5 \mathrm{~g} / \mathrm{d}$ and four calves to each level higher than $1.5 \mathrm{~g} / \mathrm{d}$.

Steers for each trial were fed individually, at an equal percentage of body weight, once daily with Calan electronic gates (American Calan, Northwood, NH). Diets fed consisted of $44 \%$ sorghum silage, $44 \%$ corn cobs, and $12 \%$ supplement (DM basis). The DM fed as a percentage of BW was adjusted as needed to minimize orts while maintaining intake near ad libitum. Average DMI was $2.0 \%$ and $2.1 \%$ of BW for Trials 1 and 2, respectively.

Weight data were collected before feeding every 28 $\mathrm{d}$, and intakes were recalculated based on current weights. Weights were taken on three consecutive days at the beginning, $d 56$, and end of each 84-d trial. Interim weights were used only for intake collections. Steers were implanted with estradiol- $17 \beta$ at the beginning of each study.

For each trial, animal performance was analyzed by plotting ADG using the slope-ratio technique (Klopfenstein et al., 1985). Trial 1 used supplemental Met level as the independent variable, whereas Trial 2 used supplemental SAA level as the independent variable. The NLIN procedure (SAS, 1985) was used to determine slopes and maximum gains. 
In Trial 1, blood was drawn by jugular venipuncture from all steers before feeding on d 56 of the study. Blood was placed on ice until it was centrifuged at 5,000 $\times g$ for $20 \mathrm{~min}$. Plasma was then composited by treatment and amount of Met supplementation. Three milliliters of plasma from each composited sample was deproteinized with $90 \mathrm{mg}$ of sulfosalicylic acid for plasma amino acid analysis (AOAC, 1984) using ion-exchange chromatography with HPLC equipment (Waters, Milford, MA).

Individual plasma amino acid concentrations were plotted against supplemental Met intake. The NLIN procedure of SAS (1985) was used to find the breakpoint in plasma concentration of Met with no initial response to supplemental Met followed by a positive slope. Such a response is characteristic of a limiting amino acid (Gibb et al., 1992a). Plasma concentrations of essential amino acids with an initial negative response followed by a plateau were also analyzed for a breakpoint. Such a pattern may identify amino acids that became limiting.

\section{Results and Discussion}

In Situ Study. After $12 \mathrm{~h}$ of ruminal incubation, escape protein of FTH was greater than that of MBM but less than that of BM $(P<.01$; Table 4$)$. Gibb et al. (1992b) reported similar escape values for the same protein sources that corresponded to observed protein efficiencies.

Table 3. Composition of diets (\%, DM basis) fed to growing steers in Trial $2^{\mathrm{a}}$

\begin{tabular}{|c|c|c|c|}
\hline \multirow[b]{2}{*}{ Ingredient } & \multicolumn{3}{|c|}{ Treatment } \\
\hline & $\mathrm{BM}^{\mathrm{b}}$ & $\mathrm{BM}+\mathrm{FTH}^{\mathrm{cd}}$ & $\mathrm{BM}+\mathrm{Met}^{\mathrm{d}}$ \\
\hline Sorghum silage & 44 & 44 & 44 \\
\hline Ground corn cobs & 44 & 44 & 44 \\
\hline Dry supplement & 12 & 12 & 12 \\
\hline Blood meal & 2.60 & 2.60 & 2.60 \\
\hline Soybean hulls & 6.52 & 3.04 & 6.39 \\
\hline Urea & 1.17 & .70 & 1.14 \\
\hline Dicalcium phosphate & .92 & .81 & .92 \\
\hline Feather meal & - & 4.06 & - \\
\hline Smartamine $\mathrm{M}^{\mathrm{e}}$ & - & - & .16 \\
\hline Salt & .30 & .30 & .30 \\
\hline Tallow & .20 & .20 & .20 \\
\hline Ammonium sulfate & .20 & .20 & .20 \\
\hline Trace mineral premix ${ }^{f}$ & .05 & .05 & .05 \\
\hline Vitamin premix ${ }^{\mathrm{g}}$ & .03 & .03 & .03 \\
\hline Selenium premix ${ }^{\mathrm{h}}$ & .01 & .01 & .01 \\
\hline
\end{tabular}

${ }^{a}$ Diets were $60 \%$ TDN, $11.1 \% \mathrm{CP}$, and $69 \% \mathrm{NDF}$.

${ }^{\mathrm{b}} \mathrm{BM}=$ blood meal, flash-dried.

${ }^{\mathrm{c}} \mathrm{FTH}=$ feather meal hydrolyzed at $145^{\circ} \mathrm{C}$ for $15 \mathrm{~min}$.

${ }^{\mathrm{d}}$ Supplements that were mixed with the blood meal control supplement to supply incremental amounts of additional metabolizable sulfur amino acids $(0, .25, .50,1,1.5,2,4$, and $6 \mathrm{~g} / \mathrm{d})$.

${ }^{\mathrm{e}}$ Contains $70 \%$ Met (Rhône-Poulenc Animal Nutrition, Atlanta, GA), $63 \%$ metabolizable Met.

${ }^{\mathrm{f}}$ Contains $10 \% \mathrm{Mg}, 6 \% \mathrm{Zn}, 2 \% \mathrm{Mn}, 4 \% \mathrm{Fe}, .5 \% \mathrm{Cu}, .3 \% \mathrm{I}$, and $.05 \%$ Co.

${ }^{\mathrm{g}} 15,000 \mathrm{IU}$ of vitamin A, 3,000 IU of vitamin D, and 3.75 IU vitamin E per gram of premix.

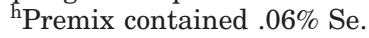

Amino acid profiles for the residue remaining after in situ incubation are reported (Table 4) and represent the composition of the protein escaping ruminal degradation. Analysis of the residue following incubation was chosen because Varvikko (1986) and Crooker et al. (1981) reported that certain amino acids were more resistant to microbial degradation than others. Likewise, Klemesrud et al. (1997b) reported that amino acid profiles of dietary protein were altered during in situ incubation.

Amino acid profiles for MBM, FTH, and BM are similar to those reported by Gibb et al. (1992b). Although the escape protein from FTH seems to be an excellent source of SAA, greater than 90\% is Cys (Table 4). Feather meal contains very little Met or Lys, which are essential amino acids often considered first-limiting (Nimrick et al., 1970; Williams and Smith, 1974). Meat and bone meal and BM, conversely, seem to be poor sources of SAA but good sources of lysine.

Digestion Study. There were no differences in true protein digestibility $(P>.15)$ among MBM, FTH, and BM (Table 5). Numerically, BM had the highest true protein digestibility $(94.0 \%)$ and FTH the lowest $(86.7 \%)$. Protein digestibility of BM is reported to be excellent, approaching 100\% (Loerch et al., 1983; Blasi et al., 1991). Although protein digestibility of MBM can be reduced by inclusion of hair (Costa, 1994) and overheating during processing (Batterham and Darnell, 1986), we obtained a value of $92.6 \%$, indicating that MBM protein was highly digestible. Although there have been reports of poor N digestibilities of FTH in swine (Knabe et al., 1989), protein digestibility of FTH in ruminants was greater than $86 \%$ (Goedeken et al., 1990b; Blasi et al., 1991). Results indicate that protein digestibility of all three products was excellent.

The true digestibilities of the amino acids in MBM, FTH, and BM, calculated by difference from the basal diet, are shown in Table 5. Results show a wide range in digestibilities of individual amino acids among the three protein feedstuffs tested. These results are consistent with those of Jorgensen et al. (1984) and Knabe et al. (1989), who have demonstrated that digestibilities of amino acids vary greatly among protein feedstuffs fed to swine.

The digestibilities of the SAA and Lys are of particular interest because these are often considered firstlimiting in cattle diets. Methionine was highly digestible, ranging from 91.2 to $130.8 \%$. The digestibility of Cys, however, was found to be very low in MBM and FTH, which is consistent with previous research with swine (Jorgensen et al., 1984; Knabe et al., 1989). This may be the result of hair in the MBM or inadequate hydrolyzation of the FTH. The high digestibility of Cys in BM may be an artifact due to the presence of very little Cys in BM. Lysine digestibility was excellent for $\mathrm{BM}$ but very low for FTH, which is consistent with the findings of Knabe et al. (1989). Results demonstrate that digestibilities of amino acids vary greatly among MBM, FTH, and BM fed to ruminants. More precise 
Table 4. Crude protein, escape protein, and amino acid composition of protein sources

\begin{tabular}{lcccc}
\hline \hline Item & Meat and bone meal & Feather meal & Blood meal & SEM \\
\hline Crude protein $^{\mathrm{a}}$ & 41.6 & 86.1 & 90.0 & - \\
Escape protein $^{\mathrm{b}}$ & $60.8^{\mathrm{d}}$ & $73.5^{\mathrm{e}}$ & $92.4^{\mathrm{f}}$ & 1.6 \\
Amino acid $^{\mathrm{c}}$ & & & & \\
Met & .9 & .5 & 1.2 & - \\
Cys & .4 & 5.1 & .7 & - \\
Lys & 3.8 & 1.7 & 7.9 & - \\
His & 1.3 & .7 & 5.8 & - \\
Phe & 2.8 & 4.6 & 6.7 & - \\
Thr & 2.3 & 3.9 & 5.1 & - \\
Leu & 4.6 & 7.8 & 11.6 & .6 \\
Ile & 1.8 & 4.2 & 7.8 & - \\
Val & 3.8 & 6.1 & 3.6 & - \\
Arg & 6.7 & 6.5 & & \\
\hline
\end{tabular}

${ }^{\text {a}}$ Expressed as a percentage of DM.

${ }^{b}$ Expressed as a percentage of CP.

${ }^{\mathrm{c}}$ Expressed as a percentage of $\mathrm{CP}$ remaining after a 12-h incubation in situ.

d,e,fValues with unlike superscripts differ $(P<.01)$.

diet formulation may be achieved if the digestibilities of amino acids in a feedstuff are taken into account.

Growth Studies. For Trial 1, ADG of steers was increased $(P<.05)$ when MBM, MBM plus $1 \% \mathrm{FTH}$, or MBM plus 2\% FTH treatments were fed compared with urea (Figure 1). Although steers fed the urea supplement were deficient in metabolizable protein, the increase in gain presumably was due to greater metabolizable protein from MBM and FTH. Addition of FTH to MBM resulted in a linear increase in ADG $(P<.01)$. This increase in gain may be due to the additional SAA and metabolizable protein that FTH provided (Table 6).

Supplementation of rumen-protected Met to steers receiving the MBM treatment improved gains. Nonlinear analysis predicted a maximum gain of $.40 \mathrm{~kg} / \mathrm{d}(.14$ $\mathrm{kg} / \mathrm{d}$ above the MBM alone; Figure 1), which was achieved by the addition of $1.5 \mathrm{~g} / \mathrm{d}$ of rumen-protected Met. Inclusion of Met in excess of $1.5 \mathrm{~g} / \mathrm{d}$ did not improve performance of steers supplemented with MBM, suggesting that Met was no longer limiting and(or) another amino acid became first-limiting. Klemesrud et al. (1997a) reported a similar improvement in ADG when rumen-protected Met was added to MBM.

The maximum gain achieved from the addition of 1.5 $\mathrm{g} / \mathrm{d}$ of rumen-protected Met to MBM was equal to the gain achieved with MBM plus 1\% FTH (Figure 1). The MBM plus $1 \% \mathrm{FTH}$ was formulated to provide $1.5 \mathrm{~g}$ of SAA. However, accounting for the poor digestibility of Cys in FTH, this value was much lower (Table 6). Regardless, FTH was an effective source of SAA. However, supplementation of rumen-protected Met to steers receiving MBM plus 1 or $2 \%$ FTH treatments also im-

Table 5. True protein digestibility, digestibility of escape protein, and digestibility of escape amino acids of protein sources

\begin{tabular}{lcccc}
\hline \hline Item & Meat and bone meal & Feather meal & Blood meal & SEM \\
\hline True protein $^{\mathrm{a}}$ & 92.6 & 86.7 & 94.0 & 4.0 \\
Escape protein $^{\mathrm{b}}$ & 87.8 & 81.9 & 93.5 & - \\
Escape AA $^{\mathrm{c}}$ & & & & \\
Met & 91.2 & 130.8 & 114.2 & - \\
Cys & 23.8 & 50.8 & 155.4 & - \\
Lys & 63.9 & 43.7 & 100.0 & - \\
His & 94.5 & 69.4 & 94.0 & - \\
Phe & 71.9 & 77.5 & 96.6 & - \\
Thr & 50.3 & 66.9 & 102.1 & - \\
Leu & 67.6 & 74.2 & 96.8 & - \\
Ile & 66.6 & 76.5 & 148.9 & - \\
Val & 75.3 & 74.0 & 97.8 & \\
Arg & 95.3 & 84.6 & 101.6 & - \\
\hline
\end{tabular}

${ }^{\text {a}}$ Expressed as a percentage of the CP. Calculated by difference from the apparent CP digestibility of urea control.

${ }^{\mathrm{b}}$ Expressed as a percentage of $\mathrm{CP}$ remaining after 12-h incubation in situ. Calculated as [(escape protein - indigestible protein)/escape protein].

${ }^{c}$ Expressed as a percentage of amino acid remaining after 12-h incubation in situ. Calculated as [(escape amino acid - indigestible amino acid)/escape amino acid]. Indigestible amino acids calculated by difference from urea control. 


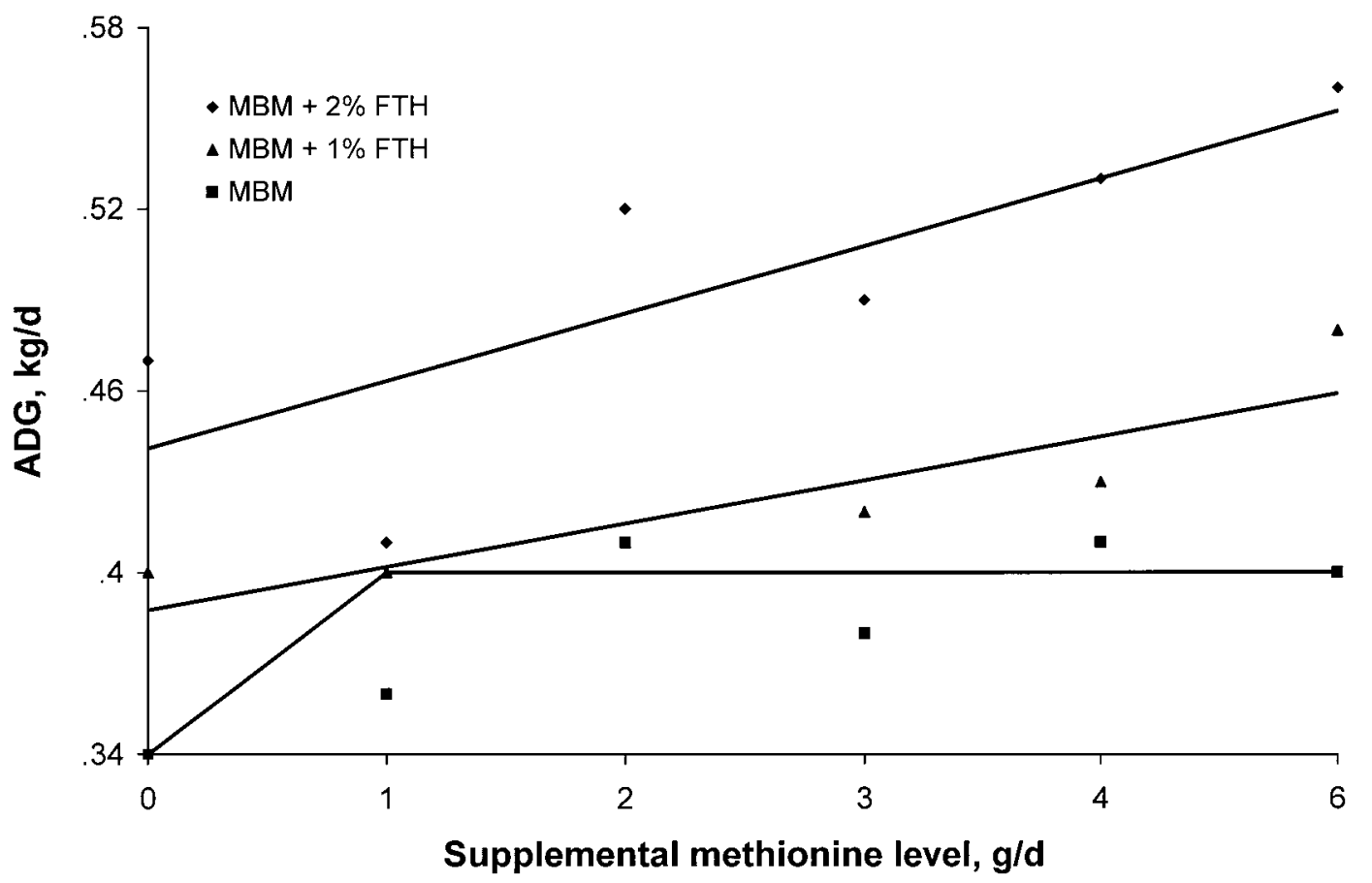

Figure 1. Regression of daily intake of metabolizable methionine against daily gain. Resulting values (slopes) represent the efficiency of methionine utilization. Standard errors of the slopes are $.019, .007, .010$ for meat and bone meal (MBM), MBM plus 1\% feather meal (FTH), and MBM plus 2\% FTH. Standard error of the maximum gain is .026 for MBM. Urea control calves gained $.27 \mathrm{~kg} / \mathrm{d}$.

proved gain. Nonlinear analysis failed to converge upon a breakpoint for either of these two treatments. The ADG response to rumen-protected Met was linear $(P<$ .10; Figure 1). Although FTH is an excellent source of SAA, the additional metabolizable protein from FTH may still be deficient in Met. The lack of a nonlinear breakpoint suggests that no other amino acid became limiting. Even though FTH can provide a portion of the SAA not available in MBM, additional Met may further improve performance.

Table 6. Ruminal escape, intestinally digestible amino acids supplied by meat and bone meal (MBM) and feather meal $(\mathrm{FTH})$, Trial $1^{\mathrm{a}}$

\begin{tabular}{lrcc}
\hline \hline & \multicolumn{3}{c}{ Treatment protein } \\
\cline { 2 - 4 } Amino acid & MBM & MBM plus 1\% FTH & MBM plus 2\% FTH \\
\hline Methionine & .6 & .8 & 1.0 \\
Cysteine & .1 & .8 & 1.6 \\
Lysine & 1.8 & 2.0 & 2.2 \\
Histidine & .9 & 1.1 & 1.2 \\
Phenylalanine & 1.5 & 2.5 & 3.6 \\
Threonine & .9 & 1.6 & 2.4 \\
Leucine & 2.3 & 4.0 & 5.7 \\
Isoleucine & .9 & 1.8 & 2.7 \\
Valine & 2.1 & 3.5 & 4.8 \\
Arginine & 4.7 & 6.4 & 8.0 \\
\hline
\end{tabular}

${ }^{a}$ Expressed as grams/day of intestinally available amino acids from meat and bone meal and feather meal. Intake of MBM or FTH based on a 228-kg animal (average initial BW) consuming 2.0\% of body weight. Intestinal availability based on values from Table 5 .
Plasma amino acid concentrations are shown in Table 7. The addition of rumen-protected Met increased plasma Met concentration for the MBM treatment. However, for all three treatments nonlinear analysis failed to converge upon a breakpoint indicative of a limiting amino acid. Additionally, no other amino acid showed an initial negative response followed by a plateau, indicative of a second-limiting amino acid. In this trial, plasma amino acid concentrations were not very useful in predicting amino acid adequacy.

For Trial 2, ADG of steers supplemented with BM was increased $(P<.05)$ by the addition of SAA, from either FTH or rumen-protected Met (Figure 2). This increase in ADG is evidence that SAA are the firstlimiting amino acids in BM, and it provides an explanation for the complementary responses observed between BM and FTH (Goedeken et al., 1990b; Blasi et al., 1991). Although steers supplemented with BM gained $.39 \mathrm{~kg} /$ $\mathrm{d}$, the addition of FTH as a source of SAA initiated a maximum gain of $.48 \mathrm{~kg} / \mathrm{d}$. Addition of rumen-protected Met to BM improved gains in comparison to FTH $(P<$ .05 ) and resulted in a maximum gain of $.57 \mathrm{~kg} / \mathrm{d}$ (Figure 2).

Under the conditions of this trial, the maximum gain response for FTH was $50 \%$ of the maximum gain response for rumen-protected Met [(.48 - .39)/(.57 - .39)]. Although FTH improves gains, the greater gains achieved with rumen-protected Met suggests that Met, rather than Cys, may still be limiting. However, FTH can provide $50 \%$ of the supplemental SAA required for maximum gain. 
Table 7. Plasma amino acid response of steers fed a urea supplement, meat and bone meal (MBM), MBM plus 1\% feather meal (FTH), or MBM plus $2 \%$ FTH with incremental amounts of rumen-protected methionine

\begin{tabular}{|c|c|c|c|c|c|c|c|c|c|c|}
\hline \multirow[b]{2}{*}{ Treatment } & \multicolumn{10}{|c|}{ Plasma amino acid concentration, $\mathrm{mg} / 100 \mathrm{~mL}$} \\
\hline & Met & Lys & His & Phe & Thr & Leu & Ile & Val & Arg & $\operatorname{Trp}$ \\
\hline Urea & .20 & 1.69 & .63 & .82 & 1.01 & 1.42 & .66 & 2.00 & .85 & .52 \\
\hline \multicolumn{11}{|l|}{$\mathrm{MBM}+$} \\
\hline 0 Met & .29 & 1.72 & .87 & 1.08 & .85 & 1.94 & 1.15 & 2.33 & 2.33 & .45 \\
\hline 1 Met & .33 & 1.02 & .17 & 1.20 & - & 1.48 & .56 & 1.36 & .33 & .34 \\
\hline $2 \mathrm{Met}$ & .37 & 2.34 & 1.25 & 1.61 & 2.68 & 2.76 & 1.16 & 2.90 & 1.98 & .93 \\
\hline 3 Met & .40 & 2.17 & .94 & 1.31 & 1.36 & 2.43 & 1.28 & 2.88 & 2.61 & .56 \\
\hline $4 \mathrm{Met}$ & .41 & 2.10 & .58 & 1.32 & 1.66 & 1.78 & .71 & 1.51 & .39 & .35 \\
\hline 6 Met & .59 & 2.70 & .87 & 1.84 & 2.14 & 2.56 & 1.19 & 2.90 & 2.29 & .84 \\
\hline \multicolumn{11}{|c|}{$\mathrm{MBM}+1 \% \mathrm{FTH}+$} \\
\hline 0 Met & .26 & 2.11 & .96 & 1.25 & 1.33 & 2.02 & .90 & 2.65 & 1.25 & .63 \\
\hline $1 \mathrm{Met}$ & .23 & 2.06 & .97 & 1.85 & - & 2.15 & 1.09 & 2.63 & 1.00 & .55 \\
\hline $2 \mathrm{Met}$ & .36 & 2.03 & 1.00 & 1.41 & 1.53 & 2.39 & 1.30 & 2.85 & 2.72 & .69 \\
\hline 3 Met & .32 & 1.88 & .91 & 1.22 & 1.64 & 1.90 & 1.07 & 2.79 & 1.80 & .65 \\
\hline 4 Met & .35 & 2.55 & 1.10 & 1.88 & 2.01 & 1.72 & .59 & 2.66 & .12 & .78 \\
\hline $6 \mathrm{Met}$ & .24 & 1.18 & .63 & .89 & .82 & 1.10 & .44 & 1.46 & .34 & .53 \\
\hline \multicolumn{11}{|c|}{$\mathrm{MBM}+2 \% \mathrm{FTH}+$} \\
\hline $0 \mathrm{Met}$ & .75 & 4.51 & 2.47 & 2.83 & 3.24 & 4.05 & 1.31 & 4.68 & 2.22 & 1.13 \\
\hline $1 \mathrm{Met}$ & .50 & 1.94 & .79 & 1.62 & 1.69 & 2.11 & .77 & 1.74 & 1.60 & .63 \\
\hline $2 \mathrm{Met}$ & .35 & 1.70 & .77 & 1.26 & 1.33 & 2.42 & 1.45 & 3.08 & 1.27 & .55 \\
\hline 3 Met & .38 & 1.88 & .89 & 1.34 & 1.57 & 2.38 & 1.34 & 3.10 & 2.07 & .65 \\
\hline $4 \mathrm{Met}$ & .23 & 1.11 & .60 & .58 & .71 & .86 & .45 & 1.16 & .94 & .57 \\
\hline $6 \mathrm{Met}$ & .37 & 1.83 & .97 & 1.18 & 1.31 & 1.72 & .51 & 1.48 & .33 & .26 \\
\hline SEM & .03 & .10 & .05 & .05 & .07 & .13 & .07 & .14 & .17 & .04 \\
\hline
\end{tabular}

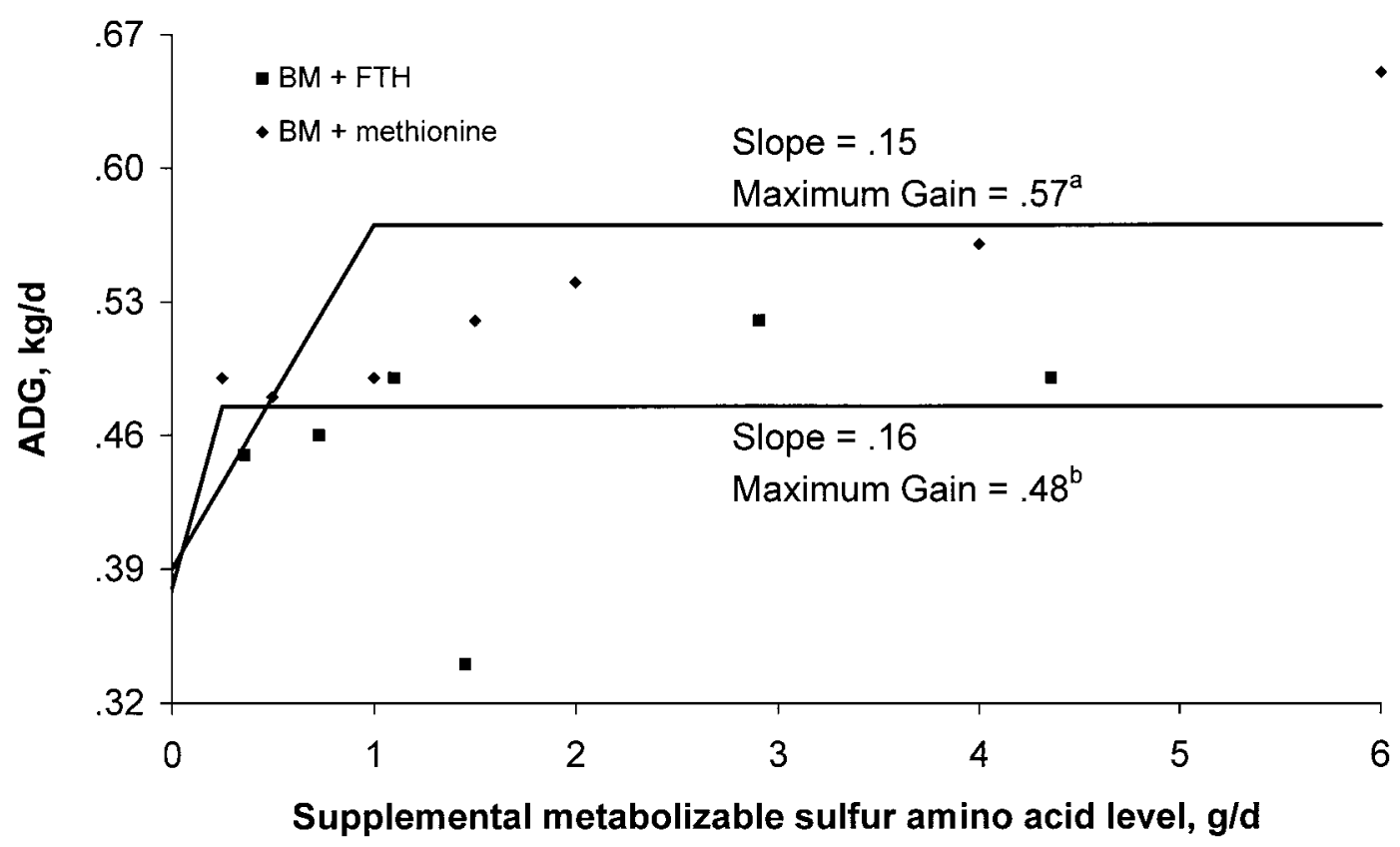

Figure 2. Regression of daily intake of metabolizable sulfur amino acids against daily gain. Resulting values (slopes) represent the efficiencies of sulfur amino acid utilization. Standard errors of the slopes are .045 and .043 for blood meal plus feather meal $(\mathrm{BM}+\mathrm{FTH})$ and blood meal plus rumen-protected methionine (BM + MET). Standard errors of the maximum gain are .028 and .028 , respectively. Values with different superscripts differ $(P<.05)$. 
Table 8. Calculated supply of metabolizable sulfur amino acids at maximum gain (Trial 2) for the blood meal + feather meal treatment ${ }^{\mathrm{a}}$

\begin{tabular}{lccc}
\hline \hline Source & Methionine & Cystine & Total SAA $^{\mathrm{b}}$ \\
\hline Basal diet & 8.2 & 7.7 & 15.9 \\
Blood meal & 1.4 & .8 & 2.2 \\
Feather meal & .1 & .5 & .6 \\
Total & 9.7 & 9.0 & 18.7 \\
\hline
\end{tabular}

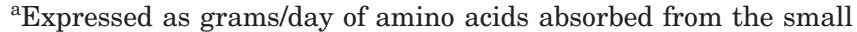
intestine of steers at maximum gain $(.48 \mathrm{~kg} / \mathrm{d})$. Based on a $263-\mathrm{kg}$ animal (average midtrial BW) consuming $2.1 \%$ of body weight.

${ }^{\mathrm{b}}$ Total sulfur amino acids (methionine + cystine).

The calculated supply of SAA for steers at the breakpoint for maximum gain was $18.7 \mathrm{~g}$ of metabolizable SAA (Table 8). Of this, $9.0 \mathrm{~g}$, or $48 \%$, was from cystine. Previous research suggests that Cys can supply nearly $50 \%$ of the total SAA requirement in rats (Shannon et al., 1972), cats (Teeter et al., 1978), dogs (Hirakawa and Baker, 1985), and pigs (Chung and Baker, 1992). Similar conclusions, based on plasma amino acid concentrations, have been reported for growing cattle (Ahmed and Bergen, 1983). These data suggest that FTH is a source of available SAA, primarily Cys. Also based on ADG response, Cys from FTH is $50 \%$ as effective as rumen-protected Met at meeting the supplemental SAA requirement of growing steers.

The forage diets used in these studies supplied energy to support .5 to $.6 \mathrm{~kg} / \mathrm{d}$ gain. These rates of gain would be typical for stocker cattle in the winter prior to summer grazing on green grass. Forage protein is generally highly degraded, and the MP supplied to the intestine of these cattle is primarily of microbial origin. As shown in these studies, Met or total SAA are limiting. Calves fed other forages or high-energy feedstuffs that supply more energy will have increased MP requirements. The proportion of each amino acid in the MP required for gain is probably constant. However, the proportion of amino acids used for maintenance decreases as the rate of gain increases. The maintenance requirement accounted for approximately 58\% of the MP requirement in the studies reported herein. The proportion of MP required for maintenance for similar calves fed highenergy diets would be approximately $32 \%$. The important question is whether the amino acid proportions differ for meeting the maintenance vs the gain requirements. The Swine NRC (1998) suggests that there is a difference, but the conclusion is based on very minimal data. For the discussion of this article, the most notable difference is the higher requirement for cystine for maintenance than for gain. This is logical because of the synthesis of keratin. Because of the greater proportion of maintenance requirement in our studies, the proportion of the total SAA requirement that could be met with Cys (about 50\%) may be larger than it would be for cattle gaining more rapidly.

\section{Implications}

Total sulfur amino acids potentially limit growth in cattle. Feather meal can provide a portion of the sulfur amino acids limiting growth. However, addition of rumen-protected methionine may result in greater gains if methionine rather than cystine is still first-limiting. When formulating ruminant diets for metabolizable amino acids, escape value and digestibility of the individual amino acids must be considered.

\section{Literature Cited}

Ahmed, B. M., and W. G. Bergen. 1983. Methionine-cyst(e)ine relationship in steers. J. Anim. Sci. 57(Suppl. 1):110 (Abstr.).

AOAC. 1984. Official Methods of Analysis (13th Ed.). Association of Official Analytical Chemists, Washington, DC.

Batterham, E. S., and R. E. Darnell. 1986. Effect of pressure and temperature on the availability of lysine in meat and bone meal as determined by slope-ratio assay with growing pigs, rat and chicks and by chemical techniques. Br. J. Nutr. 55:441-453.

Blasi, D. A., T. J. Klopfenstein, J. S. Drouillard, and M. H. Sindt. 1991. Hydrolysis time as a factor affecting the nutritive value of feather meal and feather meal-blood meal combinations for growing calves. J. Anim. Sci. 69:1272-1278.

Chung, T. K., and D. H. Baker. 1992. Maximal portion of the young pig's sulfur amino acid requirement that can be furnished by cystine. J. Anim. Sci. 70:1182-1187.

Costa, M. A. 1994. Response to escape protein supplementation by cattle grazing bromegrass/red clover pastures. M.S. thesis. Univ. of Nebraska, Lincoln.

Crooker, B. A., R. D. Shanks, J. H. Clark, and G. C. Fahey. 1981. Effects of ruminal exposure upon the amino acid profile of typical feedstuffs. J. Anim. Sci. 53(Suppl. 1):391 (Abstr.).

Gibb, D. J., T. J. Klopfenstein, R. A. Britton, and A. J. Lewis. 1992a. Plasma amino acid response to graded levels of escape protein. J. Anim. Sci. 70:2885-2892.

Gibb, D. J., T. J. Klopfenstein, and M. H. Sindt. 1992b. Combinations of rendered protein meals for growing calves. J. Anim. Sci. 70:2581-2589.

Goedeken, F. K., T. J. Klopfenstein, R. A. Stock, and R. A. Britton. 1990a. Hydrolyzed feather meal as a protein source for growing calves. J. Anim. Sci. 68:2945-2953.

Goedeken, F. K., T. J. Klopfenstein, R. A. Stock, R. A. Britton, and M. H. Sindt. 1990b. Protein value of feather meal for ruminants as affected by blood additions. J. Anim. Sci. 68:2936-2944.

Hirakawa, D. A., and D. H. Baker. 1985. Sulfur amino acid nutrition of the growing puppy: Determination of the dietary requirements for methionine and cystine. Nutr. Res. 5:631-642.

Jørgensen, H., W. C. Sauer, and P. A. Thacker. 1984. Amino acid availabilities in soybean meal, sunflower meal, fish meal and meat and bone meal fed to growing pigs. J. Anim. Sci. 58:926-934.

Klemesrud, M. J., T. J. Klopfenstein, and A. J. Lewis. 1997a. Addition of ruminal escape methionine and lysine to meat and bone meal. J. Anim. Sci. 75:3301-3306.

Klemesrud, M. J., T. J. Klopfenstein, and A. J. Lewis. 2000. Metabolizable methionine and lysine requirements of growing cattle. J. Anim. Sci. 78:199-206.

Klemesrud, M. J., T. J. Klopfenstein, A. J. Lewis, D. H. Shain, and D. W. Herold. 1997b. Limiting amino acids in meat and bone and poultry by-product meals. J. Anim. Sci. 75:3294-3300.

Klopfenstein, T., R. Stock, and R. Britton. 1985. Relevance of bypass protein to cattle feeding. Prof. Anim. Sci. 1:27-31.

Knabe, D. A., D. C. LaRue, E. J. Gregg, G. M. Martinez, and T. D. Tanksley, Jr. 1989. Apparent digestibility of nitrogen and amino 
acids in protein feedstuffs by growing pigs. J. Anim. Sci. 67:441-458.

Loerch, S. C., L. L. Berger, S. D. Plegge, and G. C. Fahey, Jr. 1983. Digestibility and rumen escape of soybean meal, blood meal, meat and bone meal and dehydrated alfalfa nitrogen. J. Anim. Sci. 57:1037-1047.

Merchen, N. R., and E. C. Titgemeyer. 1992. Manipulation of amino acid supply to the growing ruminant. J. Anim. Sci. 70:3238-3247.

Nimrick, E., E. E. Hatfield, J. Kaminski, and F. N. Owens. 1970. Quantitative assessment of supplemental amino acid needs for growing lambs fed urea as the sole nitrogen source. J. Nutr. 100:1293-1300.

NRC. 1996. Nutrient Requirements of Beef Cattle (7th Ed.). National Academy Press, Washington, DC.

NRC. 1998. Nutrient Requirements of Swine (10th Ed.). National Academy Press, Washington, DC.

Polan, C. E., K. A. Cummins, C. J. Sniffen, T. V. Muscato, J. L. Vicini, B. A. Crooker, J. H. Clark, D. G. Johnson, D. E. Otterby, B. Guillaume, L. D. Muller, G. A. Varga, R. A. Murray, and S. B. Peirce-Sandner. 1991. Responses of dairy cows to supplemental rumen-protected forms of methionine and lysine. J. Dairy Sci. 74:2997-3013.
Reis, P. J., D. A. Tunks, and L. F. Sharry. 1973. Plasma amino acid patterns in sheep receiving abomasal infusions of methionine and cystine. Aust. J. Biol. Sci. 26:635-643.

SAS. 1985. SAS User's Guide: Statistics. SAS Inst. Inc., Cary, NC.

Shannon, B. M., J. M. Howe, and H. E. Clark. 1972. Interrelationships between dietary methionine and cystine as reflected by growth, certain hepatic enzymes and liver composition of weanling rats. J. Nutr. 102:557-562.

Teeter, R. G., D. H. Baker, and J. E. Corbin. 1978. Methionine and cystine requirements of the cat. J. Nutr. 108:291-295.

Varvikko, T. 1986. Microbially corrected amino acid composition of rumen-undegraded feed protein and amino acid degradability in the rumen of feeds enclosed in nylon bags. Br. J. Nutr. $56: 131-140$

Wilkerson, V. A., T. J. Klopfenstein, R. A. Britton, R. A. Stock, and P. S. Miller. 1993. Metabolizable protein and amino acid requirements of growing cattle. J. Anim. Sci. 71:2777-2784.

Wilkerson, V. A., T. J. Klopfenstein, and W. W. Stroup. 1995. A collaborative study of in situ forage degradation. J. Anim. Sci. 73:583-588.

Williams, A. P., and R. H. Smith. 1974. Concentrations of amino acids and urea in the plasma of the ruminating calf and estimation of the amino acid requirements. Br. J. Nutr. 32:421-433. 